\title{
Specific collagen peptides benefit the biosynthesis of matrix molecules of tendons and ligaments
}

\author{
M Schunck*, S Oesser \\ From International Society of Sports Nutrition: 10th Annual ISSN Conference and Expo \\ Colorado Springs, CO, USA. 14-15 June 2013
}

\section{Background}

An intact composition of extracellular matrix (ECM) collagens, proteoglycans and elastic fibres are responsible for the constitutional strength of tendons and ligaments $[1,2]$. It is known that pathophysiological changes in the ECM could lead to reduced extension properties and diminished capacity of energy absorption of ligaments and tendons and could promote diseases like patellar tip syndrome, tendinopathy and rupture $[3,4]$.

In a clinical study it could be demonstrated that the oral ingestion of specific collagen peptides improved extension properties of the finger joints [5].

Aim of the present study was to investigate the impact of a specific collagen peptide composition (FORTIGEL ${ }^{\mathbb{B}}$ ) on the extracellular matrix of ligaments and Achilles tendons. Previous experimental studies confirmed the stimulatory impact of these bioactive collagen peptides on the ECM biosynthesis of joint cartilage tissue [6-8].

\section{Methods}

Primary fibroblasts derived from human ligaments and tendons were isolated by enzymatic digestion and seeded in monolayer cultures in a humidified incubator in $5 \%$ $\mathrm{CO}_{2}$ atmosphere at $37^{\circ} \mathrm{C}$. After $80 \%$ cell confluence regular culture medium was supplemented with $0.5 \mathrm{mg} / \mathrm{ml}$ of a specific collagen hydrolysate $\left(\right.$ FORTIGEL $^{\circledR}$, GELITA AG, Germany).

The RNA expression of matrix molecules and degenerative metalloproteinases was determined via real-time PCR after a stimulation time period of $24 \mathrm{~h}$. Moreover, the collagen, proteoglycan and elastin biosynthesis of tendon and ligament derived fibroblasts was determined using validated methods like western blotting, alcian blue staining or ${ }^{14}[\mathrm{C}]$-incorporation assay.

\section{Results}

The biosynthesis of ligament and tendon matrix molecules was clearly stimulated by FORTIGEL ${ }^{\circledR}$. The RNA expression and biosynthesis of collagen type I and III statistically significantly increased 1.2 fold to 2.4 fold in comparison to untreated control, respectively. In addition, the synthesis of proteoglycans (versican, decorin), was increased in both Achilles tendons and ligament fibroblasts.

Moreover, a statistically significant increase in the elastin biosynthesis, the most prominent component of ligament matrix, was detected. FORTIGEL ${ }^{\circledR}$ treatment leads to an approximately $50 \%$ higher elastin synthesis compared to the untreated control cells.

In contrast to these stimulatory effects the expression of matrix metalloproteinases was down regulated in both tissues after administration of the specific collagen peptides.

\section{Conclusion}

The results indicate that the specific collagen hydrolysate has a pronounced, statistically significant stimulatory impact on the biosynthesis of extracellular matrix molecules in tendons and ligament cells. Although more clinical data are desirable a FORTIGEL ${ }^{\circledR}$ administration seems to be an interesting option for the treatment and prevention of pathological changes in ligaments and tendons like tendinopathy and might reduce the risk of injuries and rupture.

$\overline{\mathrm{CRI}}$, Collagen Research Institute, Kiel, Germany 


\section{References}

1. Rumian AP, Wallace AL, Birch HL: J Orthop Res. 2007.

2. Thomopoulos S, Williams GR, Gimbel JA, Favata M, Soslowsky LJ: J Orthop Res. 2003.

3. Goncalves-Neto J, Witzel SS, Teodoro WR, Carvalho-Junior AE, Fernandes TD, Yoshinari HH: Joint Bone Spine. 2002

4. Weh L, Augustin A: Z Orthop. 1992.

5. Weh L, Petau C: Extracta Orthopaedica. 2001

6. Schunck M, Schulze CH, Oesser S: Osteoarthritis and Cartilage. 2007.

7. Schunck M, Haggenmüller D, Schulze $\mathrm{CH}$, Oesser S: Extracta Orthopaedica. 2006

8. Oesser S, Seifert J: Cell Tissue Res. 2003.

doi:10.1186/1550-2783-10-S1-P23

Cite this article as: Schunck and Oesser: Specific collagen peptides benefit the biosynthesis of matrix molecules of tendons and ligaments. Journal of the International Society of Sports Nutrition 2013 10(Suppl 1):P23.

\section{Submit your next manuscript to BioMed Central} and take full advantage of:

- Convenient online submission

- Thorough peer review

- No space constraints or color figure charges

- Immediate publication on acceptance

- Inclusion in PubMed, CAS, Scopus and Google Scholar

- Research which is freely available for redistribution

Submit your manuscript at www.biomedcentral.com/submit 